\title{
Trypanosoma vivax infection dynamics in a cattle herd maintained in a transition area between Pantanal lowlands and highlands of Mato Grosso do Sul, Brazil ${ }^{1}$
}

\author{
Charles F. Martins ${ }^{2}$, Cláudio R. Madruga ${ }^{3 *}$, Wilson W. Koller ${ }^{3}$, Flábio R. \\ Araújo $^{3}$, Cleber O. Soares ${ }^{3}$, Raul H. Kessler ${ }^{3}$, Elaine S.P. Melo ${ }^{3}$, Laura R. \\ Rios $^{3}$, Robson C.F. Almeida ${ }^{3}$, Manoel S.C. Lima Jr ${ }^{3}$, Antonio Thadeu M. \\ Barros $^{4}$ and Luiz C. Marques ${ }^{5}$
}

\begin{abstract}
Martins C.F., Madruga C.R., Koller W.W., Araújo F.R., Soares C.O., Kessler R.H., Melo E.S.P., Rios L.R., Almeida R.C.F., Lima Jr M.S.C., Barros A.T.M. \& Marques L.C. 2008. Trypanosoma vivax infection dynamics in a cattle herd maintained in a transition area between Pantanal lowlands and highlands of Mato Grosso do Sul, Brazil. Pesquisa Veterinária Brasileira 28(1):51-56. Departamento de Clínica Médica, Universidade para o Desenvolvimento do Estado e da Região do Pantanal, Rua Ceará 333, Bairro Miguel Couto, Cx. Postal 2153, Campo Grande, MS 79003-010, Brazil. E-mail: claudio.madruga @ pq.cnpq.br Trypanosoma vivax outbreaks in beef cattle in the Pantanal region of Mato Grosso do Sul state, Brazil, causes relevant economical impact due to weight loss, abortion and mortality. Cattle moved from the Pantanal to adjacent areas of this ecosystem for breeding and fattening is a common feature. Therefore an epidemiological study on breeding cows in the transition area between Pantanal lowland and adjacent highlands of Mato Grosso do Sul was performed to determine the T. vivax infection dynamics and outbreak risk. Three experimental groups were formed: Group 1 consisted of cows parasitologically negative by the Woo test and in the enzyme-linked immunosorbent assay for $T$. vivax antibody detection (Tv-ELISA-Ab); Group 2 parasitologically negative and positive in the TV-ELISA-Ab; and in Group 3 cows were parasitologically positive and with positive reactions in the TV-ELISAAb. During 24 months, the cows' dislodgment between the above established groups was monitored by Woo test and TV-ELISA-Ab exams. The tabanid population was also monitored and the highest number occurred during the rainy season. Although parasitemias were detected only in the first four samplings of the experimental period, the cows could be considered as trypanotolerant, because no clinical signs were observed. Despite the higher T. vivax incidence during the dry season, no disease symptoms were seen. Even though $T$. vivax epidemiological situation in the herd was characterized as endemic with seasonal variation, the probability of outbreaks was null within the conditions of the study.
\end{abstract}

INDEX TERMS: Trypanosoma (Dutonella) vivax, cattle, tabanids, infection dynamics, epidemiology.

\footnotetext{
${ }^{1}$ Received on September 11, 2007.

Accepted for publication on October 23, 2007.

2 Depto Clínica Médica da Universidade para o Desenvolvimento do Estado e da Região do Pantanal, Rua Ceará 333, Bairro Miguel Couto, Caixa Postal 2153, Campo Grande, MS 79003-010, Brazil.

${ }^{3}$ Embrapa Gado de Corte, Área de Saúde Animal, BR $262 \mathrm{Km} \mathrm{4,}$ Campo Grande, Mato Grosso do Sul 72002-970, Brazil. *Corresponding author: claudio.madruga@pq.cnpq.br

${ }^{4}$ Embrapa Pantanal, Rua 21 de Setembro 1880, Bairro Nossa Sra Fátima, Caixa Postal 109, Corumbá, MS 79320-900, Brazil.

${ }^{5}$ Depto Clínica Médica, Faculdade de Ciências Agrárias e Veterinárias (FCAV), Unesp-Jaboticabal, Via de Acesso Prof. Paulo Donato Castellane s/n, Jaboticabal, SP 14884-900, Brazil.
}

RESUMO.- [Dinâmica de infecção de Trypanosoma vivax em rebanho bovino mantido numa área de transição entre o Pantanal e o planalto de Mato Grosso do Sul.] Surtos de Trypanosoma vivax em bovinos de corte do Pantanal foram responsáveis por relevante impacto econômico, devido a perda de peso, abortos e mortalidade. Um manejo comum é o deslocamento de bovinos do Pantanal baixo para áreas adjacentes desse ecosistema para reprodução e engorda. Por essa razão, foi efetuado um estudo epidemiológico em rebanho de vacas movidas para uma área de transição entre Pantanal baixo e planalto do Estado de Mato Grosso do Sul para determinar a dinâmica de infec- 
ção do T. vivax e o risco de surto. Três grupos experimentais foram formados: Grupo 1; composto por vacas parasitologicamente negativas no teste de Woo e no exame sorológico de imunoadsorção enzimática para detecção de anticorpos contra T. vivax (Tv-ELISA-Ab); Grupo 2, vacas negativas parasitológicamente e com reação positiva no Tv-ELISA-Ab; e no Grupo 3, positivas parasitologicamente e no TV-ELISA-Ab. Durante 24 meses o deslocamento das vacas entre esses grupos experimentais foi determinado pelo monitoramento mensal realizado pelo teste de Woo e Tv-ELISA-Ab. Durante esse período a população de tabanídeos na área experimental foi determinada e as maiores populações ocorreram no período das chuvas. Parasitemias de $T$. vivax foram detectadas apenas nas quatro primeiras amostragens do período experimental, apesar da elevação de incidência determinada sorológicamente tenha ocorrido no período seco do ano. Portanto, $T$. vivax foi endêmico no rebanho e a ausência de manifestação clínica sugere que os bovinos sejam tripanotolerantes e o risco de surto seja nulo nas condições em que o experimento foi executado, pois a manifestação clínica da doença esta associada à presença de parasitemia.

TERMOS DE INDEXAÇÃO: Trypanosoma (Dutonella) vivax, bovinos, tabanídeos, dinâmica de infecção, epidemiologia.

\section{INTRODUCTION}

Trypanosoma (Dutonella) vivax is an extra cellular haemoprotozoan present in Africa and Latin America infecting wild and domestic ungulates. In Africa this Trypanosoma species is cyclically transmitted by Glossina sp. flies and mechanically by tabanids and other haematophagous flies, while in Latin America only mechanically by haematophagous dipterous (Dwinger \& Hall 2000). In South America T. vivax was diagnosed in French Guyana, Venezuela, Colombia, Brazil, and Bolivia (Davila et al. 2003). In the Brazilian territory this haemoprotozoan was first diagnosed in the state of Pará infecting water buffaloes (Bubalis bubalis) (Shaw \& Lainson 1972). Only after 24 years $T$. vivax was reported in other parts of the country, as in the Pantanal of Mato Grosso (Silva et al. 1996) and later on in the Pantanal of Mato Grosso do Sul (Paiva et al. 2000). More recently this haemoprotozoan also was verified in the state of Paraíba causing severe clinical manifestations (Batista et al. 2007).

The outbreaks with severe disease manifestations described in the Pantanal lowlands such as high temperature, lethargy, weakness, anemia, diarrhea, abortion, and even mortality (Silva et al. 1996) have also been described in other Latin American countries (Losos \& Ikede 1972) with relevant economical impact (Otte et al. 1994). In Brazil there are no studies comparing the pathogeny of Brazilian $T$. vivax isolates, however genetic polymorphism has been demonstrated among Pantanal isolates (Osório 2002). The host susceptibility is an important factor for the epidemiology and impact of the trypanosomiasis.
The nutritional conditions affect host resistance, since the animals with nutritional problems develop severe disease, while those without it show a benign form of the disease (Carmichael 1948). This observation was confirmed through experimental infection where the animals with appropriate feeding had a favorable prognostic (Katunguka-Rwakishaya et al. 1999). The bovine nutritional deficiency affects the innate and the adaptative immunity. The complement system, which comprises soluble component of the former type of immunity, is impaired in animals under poor nutritional conditions. This plays an important role in the control of the infection due to participation in the process of phagocytosis and T. vivax lysis (Authié \& Pobel 1990). The complement also has a regulatory activity due to involvement in the immunoglobulin isotype shifting (Tabel et al. 1980), which is important for the immunoglobulin specificity in antibody-antigen reactions. The antibody specificity for epitopes exposed to the variable surface glycoproteins (VSGs) is crucial for the elimination of this parasite through phagocytosis (Ngaira et al. 1983). Antibodies against VSGs have a neutralization function on the parasite as well as the hemolytic factors responsible for the anemia (Taylor 1998). Additionally two other roles of the complement enhance its relevance in the control of $T$. vivax infection. The first one is the augment of the lymphocyte $B$ activation due to its link to the lymphocyte B $\mathrm{CR}_{2}$ receptor (Hebell et al. 1991). The second role is a consequence of $\mathrm{C}_{3}$ complement component participation in the enhanced memory $B$ cell production which results in increased secondary humoral response that characterizes the trypanotolerant bovines (Paling et al. 1991).

The haematophagous dipterous population is another important factor in the T. vivax epidemiology. A relationship between tabanid feeding activity and incidence of $T$. vivax was verified by Otte et al. (1994). Confirming this observation Dávila et al. (2003) found higher prevalences during the rainy season when tabanid populations are increased in the Pantanal. However, it should be considered that the $T$. vivax transmission rate depends of the interaction between parasitemia level and tabanid population (Roberts et al. 1989).

In the Pantanal lowlands, the flooding which occurs during several months of the year, leads to nutritional constraint. For this reason the animals are raised for fattening in highlands of Mato Grosso do Sul. Therefore, this epidemiological study had the objective to evaluate the $T$. vivax infection dynamics and the resulting risk of outbreaks, and also the probability of spreading this haemoprotozoan outside the Pantanal wetlands.

\section{MATERIALS AND METHODS}

Experimental area. This epidemiological study was performed on a farm of Miranda county, Mato Grosso do Sul, Brazil, within the coordinates $19^{\circ} 59^{\prime} 55,3^{\prime \prime}$ latitude South and $56^{\circ} 46$ '10,5' longitude West, $120-150$ m above sea level. The pasture in the area was Brachiaria decumbens. 
Parasitological and serological diagnostics. The occurrence of Trypanosoma vivax was detected by Woo test (Woo 1969) and the specific antibodies were diagnosed through enzyme-linked immunosorbent assay (TV-ELISA-Ab) developed by Madruga et al. (2006). Both tests were used for selection and monitoring of the experimental groups.

Experimental animals. One hundred and fifty-two cows from Pantanal lowlands were divided into three groups: Group 1 consisted of cows negative by the Woo test and enzymelinked immunosorbent assay for $T$. vivax antibody detection (TV-ELISA-Ab); Group 2 consisted of cows parasitologically negative but positive in the TV-ELISA-Ab; Group 3 was composed by cows positive in both tests. Initially, the first group had 72 cows, the second 57, and the third 23 cows. After the first sampling to establish the experimental groups, the animals were left in the experimental area for 2 months for adaptation without sampling. After this period, every 2 months, according the parasitological and serological results the number of cows in each experimental group was determined. The sanitary management of this herd consisted of vaccination against footand-mouth disease, brucellosis, rabies, infectious rhinotracheitis and parainfluenza. Gastrointestinal helminthes were controlled by antihelmintics in a strategic program.

Packed cell volume. Blood samples were collected for evaluation of the packed cell volume (PCV), which was determined by microhematocrite centrifugation technique.

Tabanid survey. Tabanids were captured during one week per month for 2 years using Nzi (Mihok 2002) and canopy traps (Hribar et al. 1991). Canopy traps were baited with a visual target $(50 \mathrm{~cm}$ diameter black ball suspended under the trap) and both traps were baited with a chemical attractant (1-octen3-ol) (French \& Kline 1989). Three traps of each type were placed on the border of wooded areas in different environments. The collected insects were placed into entomological boxes for specimen determination and counting at Embrapa Gado de Corte and Embrapa Pantanal Entomology Laboratories.

Statistical analysis. Data were analyzed by student test and qui square using the program Graph Pad InStat 3.

\section{RESULTS}

The number of animals of Group 3 decreased after the introduction into the experimental area. The group consisted initially of $14.7 \%$ of the total experimental herd and decreased to $5.4 \%$ in the second sampling, and to $0.7 \%$ in the third sampling. Afterwards, until the end of the experimental work no parasites were detected by the Woo test in the blood. The packed cell volume (PCV) average in the three experimental groups during the period when parasitemia was detected is given in Table 1. After the parasitemia disappearance ( $3^{\text {th }}$ sampling) and consequently absence of Group 3, the PCV average between Group 1 and 2, was not statistically significant (P£0.05)

Table 1. Packed cell volume (PCV) means and standard deviations in the experimental groups during the period of Trypanosoma vivax detection with the Woo test

\begin{tabular}{ccccc}
\hline Sampling & \multirow{2}{*}{ Days } & \multicolumn{3}{c}{ Experimental groups } \\
\cline { 3 - 5 } & & $\begin{array}{c}\text { Group 1 } \\
\times \pm \text { s.d. }\end{array}$ & $\begin{array}{c}\text { Group 2 } \\
\times \pm \text { s.d. }\end{array}$ & $\begin{array}{c}\text { Group 3 } \\
\times \pm \text { s.d. }\end{array}$ \\
\hline $1^{\circ}$ o & 0 & $25.2 \pm 3.0_{\mathrm{a}}$ & $26.0 \pm 3.3_{\mathrm{a}}$ & $22.5 \pm 2.9_{\mathrm{b}}$ \\
$2^{\circ}$ & 90 & $35.3 \pm 3.2_{\mathrm{a}}$ & $33.9 \pm 3.6_{\mathrm{a}}$ & $33.5 \pm 4.3_{\mathrm{a}}$ \\
$3^{\circ}$ & 120 & $38.5 \pm 3.1_{\underline{a}}$ & $37.9 \pm 3.0_{\underline{a}}$ & $42.0^{*}$ \\
Average & & $33 \%$ & $32.6 \%$ & $32.7 \%$
\end{tabular}

* Only one animal; PCV average and standard deviations among groups with different letters in the same line present significant statistical difference (0.05).

until the end of the experiment $(37.5 \pm 1.2$ and $37.4 \pm 2.8$, respectively).

The initial frequency of animals with anti-Trypanosoma vivax antibodies was $52.6 \%$ in the first year, and an increased frequency from February to August was observed (Fig.1). However an expressive drop in the frequency of seropositive animals occurred in October and December of the same year (Fig.1). In the second year of the experiment, from February to October, the frequency of seropositive animals increased, then drastically diminished in December (Fig.1). At the last sampling (February 2003) the frequency was $48.5 \%$, which was not significantly distinct from the initial frequency. Also is possible to ob-

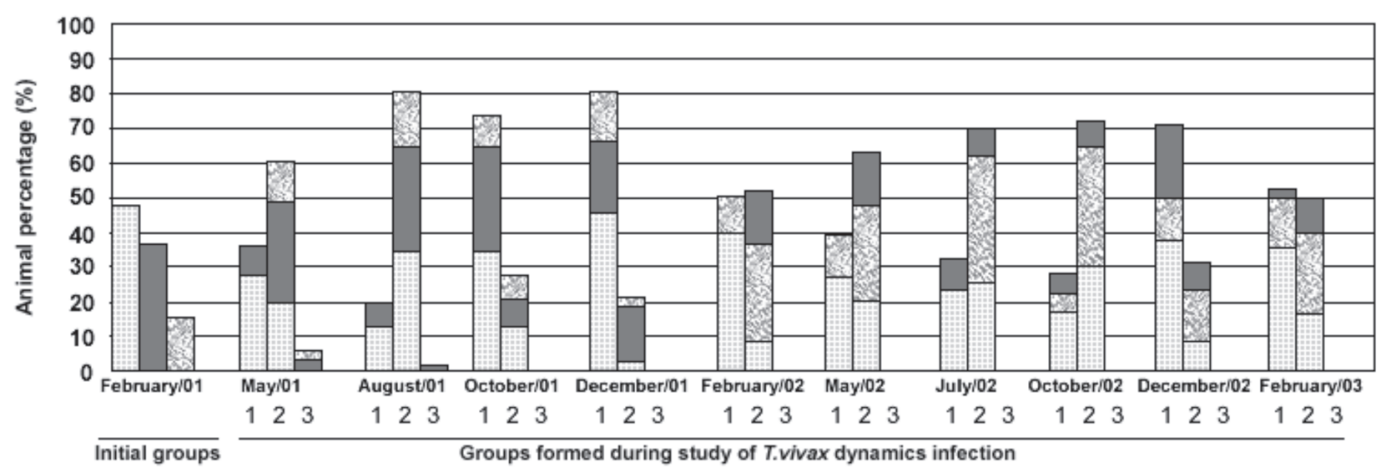

Group 1: cows negative in the parasitological Woo test and in the serological enzyme-linked immunorbent assay (TV-ELISA-Ab); Group 2: cows parasitologically negative and serologically positive; Group 3: cows positive in both tests. Initial Group 1: $\square$ Initial Group 2: $\square$ Initial Group 3: $\square$

Fig.1. Trypanosoma vivax infection dynamics in a herd of Nelore cows raised in a marginal area of Pantanal, state of Mato Grosso do Sul, in three experimental groups determined parasitologically by Woo test and serologically by indirect enzyme linked linked immunosorbent assay with crude antigen. 


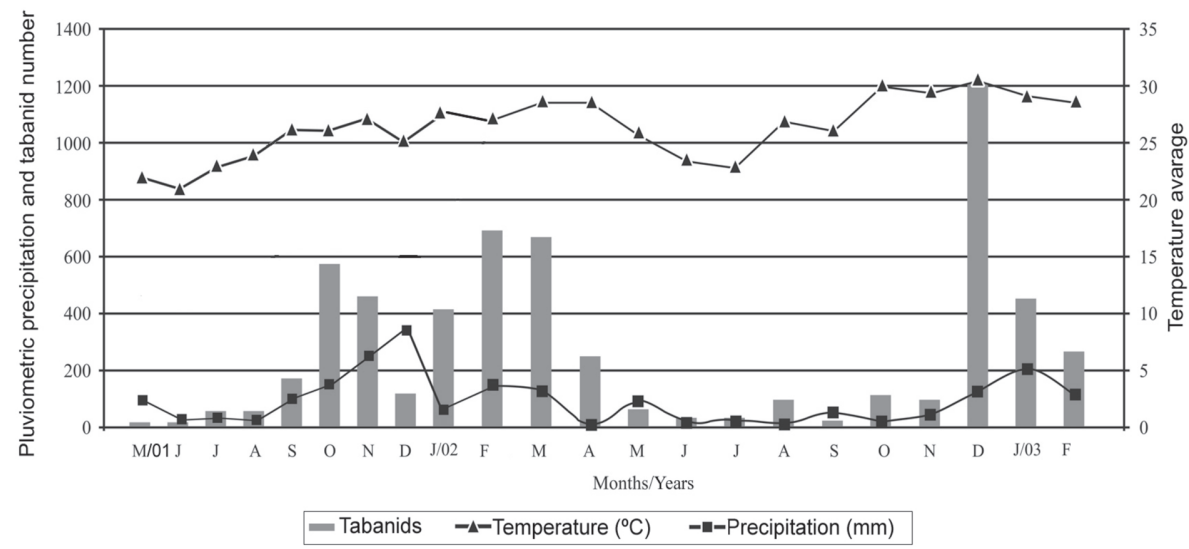

Fig. 2. Tabanid seasonal variation, total pluviometric precipitation and temperature average in the experimental area located in the marginal area of Pantanal of state of Mato Grosso do Sul.

serve in Figure 1 that throughout the experimental period variations occurred in the composition of the experimental groups with relation to the animals that belonged to the initial groups.

During the experimental period, the monthly average temperature was above $25^{\circ} \mathrm{C}$ in most of the 2-year-study, except in 4 months (May-August 2001) of the first year and 2 months (June-July 2002) of the second; but in both years the lowest temperature was not inferior to $22^{\circ} \mathrm{C}$ (Fig.2). However, monthly rainfall (MR) was variable along each year and between the years. In the first year, there was a well defined dry season from June to August 2001, with MR less than $10 \mathrm{~mm}$, and a heavier rainy season (October-December 2001) with more than $200 \mathrm{~mm}$ per month (Fig.2). In the following year the dry season extended from April to November with MR not exceeding $23.4 \mathrm{~mm}$, except in May when the precipitation was $86 \mathrm{~mm}$. Only in December 2002, the rainfall was over $100 \mathrm{~mm}$. Tabanid population peaks were observed in October/ November 2001 and February/March 2002. During the study 39 species of Tabanidae were found and 6,492 specimens were captured. The Tabanus genus was predominant and most of its specimens were $T$. occidentalis $(62.2 \%)$, followed by $T$. sorbilans $(4.7 \%), T$. palpalis (4.2\%), T. claripennis (3.8\%), and T. importunus (3.3\%). Also Lepiselaga crassipes was found in expressive number $(7.2 \%)$ as well as Fidena aureosericea (3.1\%).

\section{DISCUSSION}

Based on ELISA data, the Trypanosoma vivax infection persisted in the herd studied, but without clinical symptoms of acute trypanosomiasis, including cows of Group 1, which were free of this infection at the beginning of the experiment. Therefore, the animals were able to control the infection with this haemoprotozoan parasite. The cows' capability to circumvent $T$. vivax infection without disease expression is probably due to parasitemia control, since the hallmark of this infection is an anemia proportional to parasitemia (Silva et al. 1996).
Interaction of factors related to environment and host determined $T$. vivax infection dynamics in the herd. Contrary to what could be predictable, higher anti-T. vivax antibody frequencies arose in the dry season, when the tabanid population was lower. However, this data is in agreement with a study performed in French Guyana, where $T$. vivax infection frequency also increased in the dry season (Desquenes \& Gardiner 1993). In contrast, $T$. vivax prevalence was higher during the rainy season in the Nhecolândia subregion of the Pantanal (Dávila et al. 2003). Nevertheless, it should be taken in account that during 3 to 5 months there is an annual flooding in the Pantanal lowlands and consequently the animal population density in the remaining dry area is increased a great deal. Under these circumstances, two factors may contribute to raise the $T$. vivax incidence: (1) the pasture offers a reduced leading to nutritional constraints, and (2) the population of tabanids, which are potential mechanical vectors, increases (Barros \& Foil 1999). In the Pantanal marginal area, the vector season also coincides with the rainy season and the risk of mechanical transmission by tabanids is higher, but the pasture is abundant and of high nutritive value, contrary to what occurs in the dry season. Possibly the physical condition of the cows plays an important role in the development of $T$. vivax infection. The data on Table 1 suggest that the change of cattle from the Pantanal lowlands to adjacent areas during the rainy season improved their physical condition, because the blood PCV increased significantly between the first and third sampling as well as at subsequent evaluations. There are descriptions that nutritional stress is responsible for manifestation of severe trypanosomiasis, whereas animals with good nutritional status develop a benign infection (Carmichael 1948). Under experimental conditions, animals with appropriate feeding have a good prognosis of the Trypanosoma infection (KatungukaRwakishaya et al. 1999). Also, the hallmark clinical signal of trypanosomiasis by T. vivax, the accentuated drop of the packed cell volume, is not altered in the animals in 
normal nutri-tional conditions (Paiva et al. 2000, Schenk et al. 2001).

The innate and acquired immunity was capable of controlling the parasitemia in such way that parasitological tests did not detect $T$. vivax in the blood of the animals, what characterizes them as trypanotolerant. The innate immunity participates through diverse mechanisms, such as phagocytosis mediated by complement (Naessens et al. 2002), a serum lytic factor (Portela et al. 2000) and by a tumor necrosis factor (TNF-a) (Magez et al. 1997), although the mechanism of all factors has not been totally elucidated. Also an appropriate innate immunity has been associated with establishment of an efficient acquired immunity (Ochsenstein \& Zinkernagel 2000). The parasitemia control by innate system allows an appropriate humoral response, due to immunoglobulin shifting from $\lg M$ to IgG that enhance the specificity and avoid immunopathological events caused by IgM. On the other hand, $\operatorname{lgG}_{1}$ has been associated with cattle trypanotolerance (Naessens et al. 2002), because it recognizes epitopes on Trypanosoma internal molecules, also called hidden epitopes (Williams et al. 1996).

Therefore, the increased frequency of anti-T. vivax antibodies during the dry season could be due to a low level of $T$. vivax recurrence as consequence of nutritional stress. Another source of infection could be newly infected cattle despite the reduced population of mechanical vectors. The Trypanosoma recurrence is related to poorer nutritional conditions of the herd, which occurs during the dry season. The $T$. vivax recurrence is due to sequestration of this haemoprotozoan in the nervous system and aqueous humor where the immune system does not act, turning the animals into carriers for a long time (Whitelaw et al. 1988). Another possibility for positive serological reactions would be crossed reactions with other trypanosomes endemic for cattle in the Pantanal region, such as $T$. theileri and $T$. evansi. Nevertheless, the first species does not show crossed reaction with $T$. vivax (Luckins 1977), but the latter Trypanosoma species has antigens that induce antibodies which display cross-reactions with T. vivax (Camargo et al. 2004). However, the reduced level of cross-reactions in the ELISA test used with sera of animals infected with $T$. evansi (Madruga et al. 2006) and the low prevalence of this haemoprotozoan in the Brazilian and Bolivian Pantanal (Franke et al. 1994, Dávila et. al. 2003, Gonzales et al. 2007) implies that this Trypanosoma at the most affected only slightly the $T$. vivax frequency.

The tabanids present in the Pantanal marginal area were also responsible for maintenance of $T$. vivax in the experimental herd, since $T$. importunus and $T$. nebulosus have been proven to be the mechanical vectors of $T$. vivax in South America (Otte \& Abuabara 1991). Therefore, in Latin America the mechanical transmission mode is effective enough to maintain this haemoprotozoan in spite the absence of biological transmission by Glossina spp. (Cherenet et al. 2004)
Despite the seasonal variation and the higher T. vivax incidence in the dry season, and even if the factors that lead to trypanosomiasis outbreaks have not been elucidated, it could be concluded after 2 years of herd monitoring, that trypanosomiasis outbreak probability is null under the conditions of this study. Therefore, outside the Pantanal cattle under satisfactory management probably will not develop trypanosomiasis by $T$. vivax, but potentially they can spread the infection under nutritional stress if mechanical vectors are present such as occurred in the marginal area of Pantanal.

\section{REFERENCES}

Akol G.W.O., Authié E., Pinder M., Moloo S.K., Roelants G.E. \& Murray M. 1986. Susceptibility and immune responses of Zebu and Taurine cattle of West Africa to infection with Trypanosoma congolense transmitted by Glossina morsitans centralis. Vet. Lmmunol. Immunopathol. 1:361-373.

Authié E. \& Pobel T. 1990. Serum haemolytic complement activity and C3 levels in bovine trypanosomiasis under natural conditions of challenge early indications of individual susceptibility to disease. Vet. Parasitol. 35:43-59.

Barros T. \& Foil L. 1999. Seasonal occurrence and relative abundance of Tabanidae (Diptera) from the Pantanal region. Mem. Entomol. Int. 14:387-396.

Batista J.S., Riet-Correa F., Texeira M.M., Madruga C.R., Simões S.D. \& Maia T.F. 2007. Trypanosomiasis by Trypanosoma vivax in cattle in the Brazilian semiarid: Description of an outbreak and lesions in the nervous system. Vet. Parasitol. 31:174-81.

Camargo R.E., Uzcanga G.L. \& Bubis J. 2004. Isolation of two antigens from Trypanosoma evansi that are partially responsible for its cross reactivity with Trypanosoma vivax. Vet. Parasitol. 123:67-81.

Carmichael J. 1948. The epidemiology of trypanosomiasis in man and animals. J R Soc Med. 41:551.

Cherenet T., Sani R.A., Panandam J.M., Nadzar S., Speybroeck N. \& van den Bossche P. 2004. Seasonal prevalence of bovine trypanosomiasis in a tsé-tsé infested zone and tsé-tsé free zone of Anhara region North West Ethiopia. Onderstepoort J. Vet. Res. 71:7-312.

Dávila A.M.R., Herrera H.M., Schlebinger T., Souza S.S. \& Traub-Cseko Y.M. 2003. Using PCR for unraveling the cryptic epizootiology of livestock trypanosomosis in the Pantanal, Brazil. Vet. Parasitol. 117: 1-13.

Desquesnes M. \& Gardiner P.R. 1993. Épidémiologie de la trypanosome bovine (Trypanosoma vivax) en Guyana Française. Rev. Elev. Med. Vet. Pays Trop. 46:463-470.

Dwinger R.H. \& Hall M.J.R. 2000. Trypanosomosis due to Trypanosoma vivax in ruminants in Latin America, p.50-55. In: Animal Tripanosomosis: diagnosis and epidemiology. FAO, Roma.

Franke C.R., Greiner M. \& Mehlitz D. 1994. Monitoring of clinical, parasitological and serological parameters during an experimental infection of capybaras (Hydrochaeris hydrochaeris) with Trypanosoma evansi. Acta Trop. 58:59-169.

French F.E. \& Kline D.L. 1989. 1-Octen-3-ol, an effective attractant for Tabanidae (Diptera). J. Med. Entomol. 26:459-461.

Gonzales J.L., Chacon E., Miranda M., Loza A. \& Siles L.M. 2007. Bovine trypanosomosis in the Bolivian Pantanal. Vet. Parasitol. 146:9-16.

Hebell T., Ahearn J.M. \& Fearon D.T. 1991. Suppression of the immune response by a soluble complement receptor of B lymphocytes. Science 254:102-105.

Hribar L.J., Leprince D.J. \& Foil L.D. 1991. Design for a canopy trap for colleting horse flies (Diptera: Tabanidae). Operational and Scientific Notes 23:657-659.

Katunguka-Rwakishaya E., Murray M., Holmes P.H. 1999. The influence of energy intake on some blood biochemical parameters in Scottish 
blackface sheep infected with Trypanosoma congolense. Vet. Parasitol. 84:1-11.

Losos G.J., Ikede B.O. 1972. Review of pathology of disease in domestic and laboratory animals caused by Trypanosoma congolense, T. vivax, T. brucei, T. rhodesiense and T. gambiense. Vet. Pathol. 9:1-71.

Luckins A.G. 1977. Detection of antibodies in trypanosome-infected cattle by means of a microplate enzyme-linked immunosorbent assay. Trop. Anim. Health Prod. 9:53-62.

Madruga C.R., Araújo F.R., Cavalcante-Goes G., Martins C.F., Pfeifer I.B., Ribeiro L.R., Kessler R.H., Soares C.O., Miguita M., Melo E.P.S., Almeida R.C.F. \& Lima Jr M.S.C. 2006. The development of an enzyme-linked immunosorbent assay for Trypanosoma vivax antibodies and its use in epidemiological surveys. Mem. Inst. Oswaldo Cruz 101:801-807.

Magez S., Geuskens M., Beschin A., del Favero H., Verschueren H., Lucas R., Pays E. \& de Baestselier P. 1997. Specific uptake of tumor necrosis factor-alpha is involved in growth control of Trypanosoma brucei. J. Cell Biol. 137:715-727.

Mihok S. 2002. The development of a multipurpose trap (the Nzi) for tsetse and other biting flies. Bull. Entomol. Res. 92:385-403.

Naessens J., Teale A.J. \& Sileghem M. 2002. Identification of mechanisms of natural resistance to African trypanosomosis in cattle. Vet. Immunol. and Immunopathol. 87:187-194.

Ngaira J.M., Nantulya V.M., Musoke A.J. \& Hirumi K. 1983. Phagocytosis of antibody-sensitized Trypanosoma brucei in vitro by bovine peripheral blood monocytes. Immunol. 49:393-400.

Ochsenstein A.F. \& Zinkernagel R.M. 2000. Natural antibodies and complement link innate acquired immunity. Immunol. Today 21:624-630.

Osório A.L.A.R. 2002. Polimorfismo genético de Trypanosoma (Duttonella) vivax no Pantanal Brasileiro e caracterização antigênica e ultra-estrutural de suas frações subcelulares. PhD Thesis, FIOCruz, Rio de Janeiro. 105p.

Otte M.J. \& Abuabara J.Y. 1991. Transmission of South American Trypanosoma vivax by the neotropical horsefly Tabanus nebulosus. Acta Trop. 49:73-76.

Otte M.J., Abuabara J.Y. \& Wells E.A. 1994. Trypanosoma vivax in Colombia: epidemiology and production losses. Trop. Anim. Hlth Prod. 26:146-156

Paiva F., Lemos R.A.A., Nakasato L., Mori A.E., Brum K.B. \& Bernardo K.C. 2000. Ocorrência de Trypanosoma vivax em bovinos do Estado de Mato Grosso do Sul, Brasil. I. Acompanhamento clínico, laboratorial e anatomopatológico de rebanhos infectados. Revta Bras. Parasitol. Vet. 9(2):135-141.

Paling R.W., Moloo S.K., Scott J.R., McOdimba F.A., Logan-Henfrey L.L., Murray M. \& Williams D.J.L. 1991. Susceptibility of N'Dama and Boran cattle to tsé-tsé-transmitted primary and rechallenge infections with a homologous serodeme of Trypanosoma congolense. Parasit. Immunol. 13:413-425.

Portela M., Raper J. \& Tomlinson S. 2000. An investigation in the mechanism of trypanosome lysis by human serum factor. Mol. Biochem. Parasitol. 110:273-282.

Roberts L.W., Wellde B.T., Reardon M.J. \& Onyango F.K. 1989. Mechanical transmission of Trypanosoma brucei rhodesiense by Glossina morsitans morsitans (Diptera: Glossinidae). Ann. Trop. Med. Parasitol. 83:127-131.

Schenk M.A.M., Mendonça C.L., Madruga C.R., Kohayagawa A. \& Araújo F.R. 2001. Avaliação clínico-laboratorial de bovinos Nelore infectados experimentalmente com Trypanosoma vivax. Pesq. Vet. Bras. 21:157-161.

Shaw J.J., Lainson R. 1972. Trypanosoma vivax in Brasil. Anim Trop Med Parasitol. 66:25-32.

Silva R.A.M.S., Silva J.A., Schneider R.C., de Freitas J., Mesquita D., Ramirez L., Dávila A.M.R. \& Pereira M.E.B. 1996. Outbreak of trypanosomiasis due to Trypanosoma vivax (Ziemann, 1905) in bovines of the Pantanal, Brazil. Mem. Inst. Oswaldo Cruz 9:561-562.

Tabel H., Losos G.J. \& Maxie M.G. 1980. Experimental bovine trypanosomiasis (Trypanosoma vivax and T. congolense). II. Serum levels of total protein, albumin, hemolytic complement, and complement component C3. Tropenmed. Parasitol. 31:99-104.

Taylor K.A. 1998. Immune responses of cattle to African trypanosomes: protective or pathogenic. Int. J. Parasitol. 28:219-240.

Whitelaw D.D., Gardiner P.R. \& Murray M. 1988. Extravascular foci of Trypanosoma vivax in goats: the central nervous system and aqueous humor of the eye as potential sources of relapse infections after chemotherapy. Parasitology 7:51-61.

Williams D.J.L., Taylor K.A., Newson J. \& Gichuki B. 1996. The role of anti-variable surface glycoprotein antibody responses in bovine trypanotolerance. Parasite Immunol. 18:209-218.

Woo P.T.K. 1969. The hematocrit centrifuge for the detection of trypanossomose in Blood. Can. J. Zool..47:921. 